\title{
THE RELATIONSHIP BETWEEN MINDFUL PARENTING, COGNITIVE PARENTAL AWARENESS, AND THE SUBJECTIVE WELL-BEING OF ADOLESCENTS
}

\author{
Maja Ljubetić, Ina Reić Ercegovac \\ Faculty of Humanities and Social Sciences, \\ University of Split, Croatia \\ ljubetic@ffst.hr; inareic@ffst.hr
}

Received: 15 December 2019

\begin{abstract}
The aim of this research is to explore the relationship between mindful parenting, cognitive parental awareness, and adolescents' subjective well-being. The study included 101 families consisting of a mother, a father, and an adolescent child $(N=303)$ aged 10 to 17 , with a total of 69 female adolescents and 32 male adolescents. A general data questionnaire, mindful parenting questionnaire, and cognitive parental awareness questionnaire were administered to parents while adolescents completed a general data questionnaire, loneliness scale, life and family satisfaction scales, and general self-esteem scale. The results showed that male adolescents were more satisfied with life and had higher self-esteem than female adolescents. Measures of parenting were significantly related between mothers and fathers. The results also suggest that mindful parenting and cognitive parental awareness are significant correlates to the subjective well-being of adolescents when it comes to fathers, but not to mothers.
\end{abstract}

Key words: mindful parenting, cognitive parental awareness, adolescents, life satisfaction, self-esteem, loneliness

\section{Introduction}

Family and parenting are phenomena whose value and importance to the individual and society have been researched for decades by scholars from various scientific disciplines. The interpretations of these scholars depend on the social moment, culture, religious dogmas, 
political beliefs, social and other norms, and the results of scientific research in a given period. The dominant theories that have shaped the scientific perception of family and parenting, including behavioural and psychoanalytic theories, theories of family systems (Satir, 1983, 1988; Bennett and Grimley, 2001; Bronfenbrenner, 2005), or holistic and development-oriented approaches to parenting development (Demick, 2002), reveal that, an orientation towards the child in the family context has dominated, albeit with a focus on the mother's role. The father's role has long been unfairly marginalized (Bezinović and Smojver Ažić, 2000; Sirridge, 2001). The fact that the father is an extremely important factor in shaping the child's personality and one of the key factors of a two-parent, healthy, harmonious family function has not been adequately acknowledged. From the socio-psychological perspective, the authors argue that fatherhood is a desirable, but not indispensable social role for men (Feeney et al., 2001), while others believe that fatherhood is an essential quality of masculinity (Cabrera et al., 2000). Fathers are undoubtedly important in raising children and can have a strong influence on their children. Still, their role in the process of childrearing can be viewed from different standpoints. For example, Sirridge (2001) emphasizes that the uniqueness of fathers' influence lies in their biological experience of manhood, as well as in the social and cultural aspects and manhood. This interpretation is a consequence of a neo-conservative understanding of the role of fathers in the family, resulting from the fact that fathers have no experience of pregnancy and lactation, and thus no instinct for raising children (Silverstein and Auerbach, 1999; Kušević, 2011). This simplistic interpretation of paternity is unsustainable in scientific discourse. From a different standpoint, Silverstein and Auerbach (1999) emphasise that it is impossible to marginalise other aspects of the father's role in the life of the family, particularly in light of contemporary social developments and the existence of a wide range of families that differ extensively in their structure. In this context, it is justified to consider parenting (motherhood and fatherhood) as a "relationship, role and process" (Ljubetic, 2007, 45) and the mother/father as "mutually exchangeable" (Silverstein and Auerbach, 1999, 397). The focus in research into the how fathers contribute to child (family) well-being should be on fathers' engagement, relationship quality, and responsible behaviour in parenting.

Unlike the traditional interpretation, a contemporary view of parenting implies an "equal parenting partnership" (Čudina-Obradović 
and Obradović, 2006, 265). McDermott points out that "early theories of parent and child development are inadequate to explain the complex social-contextual world of parents and children we serve today" (McDermott, 2008, 37). Therefore, "optimistically coloured" theories are more appropriate, such as family systems theory, social relationships theory, theory of empowerment and family forces, parent development theory, etc., which aim to explain systems of relationships, social interactions, and parental competencies. Parenting is an important and demanding life role (Moriarty and Fine, 2001; Juul and Jensen, 2010); it represents a challenge to parents, it is unpredictable and uncertain, and includes the "skilled and creative use of knowledge, experience and methods" (Arendell, 1997) in caring for and raising children, as well as in forming and developing a family culture. This culture is formed by both parents equally, who thus create an environment that is more or less suitable for the healthy and complete development of children and all their potential.

In the context of parenting, the constructs of parenting behaviours or styles are most often investigated; the impact of implicit parenting - which includes parental thinking, attitudes, perception of their child, their parenting role, and their impact on the developmental outcomes of children and young people - has been researched far less. The aim of this research is thus to examine the relationship between these parenting categories and some indicators of the well-being of adolescent children.

In the context of parenting, adolescence is often considered a special challenge and a period of increased parenting stress (Putnick et al., 2010). It requires modifications in parental thinking and performance because of the numerous changes children of this age undergo (Flynn, 2000), which have an impact on their physiological, hormonal, cognitive, emotional, and social levels. In addition, the adolescence of children often coincides with parents' transition to middle age; this is a demanding transition in which parents experience a decline in cognitive and physical function for the first time, as well as mid-life crisis (Freund and Ritter 2009; Lachman 2004; Keresteš et al., 2011). Early adolescence, which usually lasts from the ages of 11 to 14 , is characterized by the process of deidealising primarily parents, but also friends and oneself, which serves as a kind of trigger to exit childhood (Rudan, 2004). In addition to deidealisation, a greater focus on oneself is one of the major features of this period; this often leads to conflict with par- 
ents, which usually increases during adolescence (Collins and Laursen 2004; Smetana et al., 2006). Middle adolescence, which lasts until the ages of $17-18$, is characterized by the adolescent's strong need to connect with peers and to belong to peer groups and other social groups (Rudan, 2004). Also, a narcissistic shift and object removal followed by the mourning process continue from early adolescence, and are even more pronounced in middle adolescence (Rudan, 2004). These very processes likely also contribute to the increased sense of loneliness that is especially pronounced among adolescents (Qualter et al., 2015; Heinrich and Gullone, 2006). The need to redefine relationships with parents occurs during late adolescence, the end of which is difficult to determine either chronologically or biologically. Regardless, the end of adolescence is psychologically marked by the formation of identity, including professional and gender identity, ego synthesis, emotional independence from one's parents, responsibility, and mature relations with others (Havighurst, 1972; Erikson, 1968; 1980).

Previous research has shown that positive parenting practices, regardless of the age of the child, are marked by features of authoritarian style, i.e. high warmth, acceptance, and support for the child, as well as optimal behavioural control (Amato and Fowler, 2002; Maccoby and Martin, 1983). In addition to this, adolescents' independence, i.e. low psychological control by parents, is particularly important in adolescence (Macuka, 2007; Lansford et al., 2014; Vansteenkiste et al., 2014). Recently, in the context of adolescence, the concept of mindful parenting has increasingly attracted the attention of researchers. McCaffrey (2015) defines mindful parenting as intentionally directing attention to one's child and parenting with an emphasis on the nonjudgmental acceptance of self and child. Duncan et al. (2009) define it as a multidimensional construct that includes listening with attention, non-judgmental acceptance of self and child, emotional awareness of self and child, self-regulation in parenting, and compassion for self and child. The results on the relationship between mindful parenting and developmental outcomes of adolescents, including indicators of subjective well-being, are not entirely consistent. Some research results point to the positive effects of mindful parenting on the quality of parent-adolescent interaction (Lippold et al., 2015; Coatsworth et al., 2010). Some research has shown that, of all the dimensions of mindful parenting, only non-judgmental acceptance of parental functioning and the child are associated with lower levels of adolescent internalisation problems 
(Geurtzen et al., 2015). In a short-term longitudinal study, Tak et al. (2015) found that mindful parenting was not predictive of depressive symptoms in adolescents over a period of six months, although negative correlations were found between mindful parenting and adolescent depression in the first wave of studies. The mechanisms that mindful parenting uses to shape the parent-child interaction are reductions in stress, reactivity, and excessive preoccupation (McCafrey, 2015), which is especially important during adolescence, when conflicts between parents and adolescents are relatively common.

In addition to mindful parenting, this research also seeks to examine the role of cognitive parental awareness as regards a set of cognitions that include the concept of the child, the parental role, and the process of parenting, which is the basis for parental practices and parental behaviour as external or manifest forms of parental awareness. Parents' cognitive structures represent stable patterns of thinking, which then affect parenting experiences and shape parenting behaviours (Newberger, 1980; Reić Ercegovac, 2010). In this context, within the framework of a developmental approach to parenting studies, Newberger's 1980s conceptualisation is particularly interesting, as it introduces the concept of cognitive parental awareness (Newberger, 1977; 1980; 1987). Newberger distinguishes between parental awareness as a fundamental cognitive structure of concepts, people, and roles, and parental attitudes that reflect more superficial attitudes about caretaking behaviours and styles, i.e. parenting practice (Reić Ercegovac, 2010). Newberger (1980) distinguishes among four levels of cognitive development of parenting; from the egoistic level, in which the parent is focused solely on his own needs and interests, the conventional level, in which the most important parental task is to to impose discipline and fulfil traditional parenting norms, the subjective-individualistic level, in which the parent views the child as a separate being, i.e. a unique individual with distinctive characteristics that affect his interaction with the child, and the process-interactional level, in which the parent perceives both himself and his child as complex and dynamic psychological subsystems that are constantly interacting. Research has shown that parental awareness is correlated with years of experience, however no correlation has been found with parents' gender, race, or social status (Demick, 2002).

Although the two key parental constructs in this research may seem similar, mindful parenting is more about intentionally directing attention to the child and parent-child interactions followed by non-judg- 
mental acceptance of self and child, while cognitive parental awareness refers primarily to parental cognitions about the child and parenting that shape parenting behaviors. Consequently, one of the purposes of the current research is to examine the relationship between these two parental constructs.

\section{Research aims, problems, and hypotheses}

The aim of this research is to investigate whether there is a correlation between mindful parenting, parental cognitive awareness, and the subjective well-being of adolescents. Subjective well-being is a complex construct that includes emotional and cognitive aspects. High well-being means more positive than negative affect and high life satisfaction (Pavot and Diener, 1993) in which can be divided into satisfaction with different areas of life. Research has shown that, apart from personality traits, self-esteem is a strong correlate of subjective wellbeing (Diener and Diener, 1995). Furthermore, research has shown that loneliness is negatively related to subjective well-being (Tu and Zhang, 2014; Hombrados-Mendieta et al., 2013; Mellor et al., 2008) and that can be especially important in adolescence. Specifically, loneliness is more pronounced in this developmental stage (Qualter et al., 2015; Heinrich and Gullone, 2006) due to separation from parents and the emerging need for autonomy and privacy. Therefore, for the purposes of this paper, the well-being of adolescents is operationalised through the constructs of life satisfaction, family satisfaction, self-esteem, and loneliness. In order to achieve this aim, the research will attempt to answer the following research questions:

1. Is there a difference between male adolescents and female adolescents with regard to subjective well-being?

2. Is there a correlation within the family (between mothers and fathers) as regards mindful parenting and cognitive parental awareness?

3. Is there a correlation between mindful parenting, the cognitive parental awareness of mothers, and the well-being of adolescents?

4. Is there a correlation between mindful parenting and the cognitive parental awareness of fathers and the well-being of adolescents? 
The research begins from the assumed higher well-being of male adolescents as compared to female adolescents, as data from previous research indicates a significant decline in female psychological wellbeing during adolescence (Kalebić Jakupčević and Reić Ercegovac, 2016; Robins and Trzesniewski, 2005). The research also begins from the assumed contemporary parenting partnership, i.e. the expectation that the roles of both mother and father are significant and important determinants in the developmental outcomes of adolescents. Therefore, a significant correlation is expected between the parental variables of both mother and father and adolescent well-being indicators.

\section{Method}

\section{Sample}

The research was carried out on a convenience sample of 303 participants, i.e. 101 two-parent families consisting of a mother, father, and an adolescent aged 10 to 17 whose average age was $\mathrm{M}=15.38$, $\mathrm{SD}=2.44$. The sample included early and middle adolescents, higher elementary school pupils from one school, pupils from one urban secondary school, and pupils from one urban gymnasium. There were 69 female adolescents and 32 male adolescents in the sample. The research was carried out on school premises using encrypted questionnaires pupils filled out in class; the questionnaire for parents was provided in a sealed envelope for parents to fill out at home. Parents also returned the questionnaires to their children's respective school in a sealed envelope. The research was conducted in accordance with ethical standards, participation was voluntary and anonymous, and the participants were free to withdraw from the research at any point. Given that some of the questionnaires were not returned by parents, and that only one of two parents filled out the questionnaire for some adolescents, a total of 303 questionnaires were subjected to further analysis. The data were analysed using STATISTICA 13 software.

\section{Instruments for parents}

The general questionnaire for parents consisted of five closed type questions to collect data on parent gender and age, educational level, 
number of children in the family, and the order of birth of the child for whom they were completing the instruments.

The Mindfulness in Parenting Questionnaire (McCaffrey, 2015) was used with the permission of its author. It examines the mindful parenting of parents of children aged 2 to 16 years. It consists of 28 statements that measure two factors: Parental Self-Efficacy (e.g. How often did you consider your child's feelings before disciplining your child?) and Being in the Moment with Child (for example, How often did you carefully listen and tune into your child when you two were talking?) (McCaffrey, 2015). The participants' task is to evaluate how often they think or behave in the way described in the items by circling the appropriate rating on a five-point scale from 1 (never) to 5 (always). The reliability of subclasses in this study was Cronbach $\alpha=.88$ for the Parental Self-Efficacy subscale $(\mathrm{M}=59.00$; SD $=7.05$ ) and Cronbach $\alpha=.86$ for the Being in the Moment with Child subscale $(\mathrm{M}=52.26 ; \mathrm{SD}=6.11)$. Higher results point to a higher degree of mindful parenting.

The Cognitive Parental Awareness Scale, which is based on Newberger's (1980) concept of cognitive parental awareness, was designed for the purpose of this research with the aim of encompassing the concept of understanding parenting and the child at the cognitive level. Specifically, mindfulness in parenting refers more to actual attention to interaction the child, while the concept of parental cognitive awareness refers to a more stable and consistent understanding of the child and parenting, which in turn may subsequently reflect on mindfulness in the interaction. The scale consists of 17 items constructed to present different levels of understanding the child and parental roles, as described by Newberger (1980). The participants' task was to assess their level of agreement on a five-degree scale from 1 (disagree completely) to 5 (agree completely). Factor analysis using the principal component method with a varimax normalised rotation showed a three-factor structure (Table 1) that provides insight into the cognitive awareness of the parents who participated in this research. The first factor (seven items) describes the pessimistic perspective of parenthood, highlights the parent's passive role in parenting, and negates the child's right to his own opinion and assertiveness. "Being a slave" to social norms, the expectations of one's environment, religious beliefs, culture, tradition, and inherited values transforms a parent into a "parent-implementer" instead 
of the creator of his own parenting. The content of this factor is compatible with both the egoistic and conventional orientations of Newberger's parenthood (1980), so it was labelled the egoistic-conventional orientation. The difference between the original conceptualisation and the one obtained in the current research (differentiating between egoistic and conventional orientation vs. one factor) can be explained in several ways, including different methodologies and time of model development. Specifically, Newberger (1980) performed qualitative studies including interviews with parents, but did not test his developed model quantitatively. Also, given the time at which she offered her conceptualisation, it is possible (and very likely) that there has been a shift in the way parenting and parent-child interactions are perceived. Egoistic and conventional orientations in contemporary parenting are actually quite close; together, they constitute a perception of parenting that is predominantly "traditional", with a conventional orientation including those cognitions that are an integral part of the egoistic orientation in parenting (parental desires and interests come first; importance of obedience; authoritarianism in parenting styles). The second factor (six items) describes a more optimistic perspective of parenthood, including an active parent role and parents as individuals with their own rights and needs, with full respect for children and their active participation in the upbringing process. Reciprocity in upbringing, harmonised fulfilment of needs, and partner relationship between parents and children refer to parenthood understood as the relationship, role, and process (Ljubetić, 2007). This factor is, therefore, also defined as a factor of process-interaction orientation (Newberger, 1980). The third factor (three items) centres around children's and parents' focus on the wishes and needs of the child (parental activity aimed at meeting the needs of the child, accommodating parental behaviour to the child's needs and desires). The content of this factor is in line with Newberger's subjective-individualistic orientation (1980). A higher score on each subscale indicates that a particular orientation is more pronounced in the perception of the child and parental role. 
Table 1. Factor structure of the Cognitive Parental Awareness Scale

\begin{tabular}{|c|c|c|c|c|}
\hline & Statements & F1 & $\mathbf{F 2}$ & F3 \\
\hline 1. & $\begin{array}{l}\text { Religious beliefs have a significant influence on } \\
\text { parental behaviour. }\end{array}$ & .67 & .13 & -.04 \\
\hline 2. & $\begin{array}{l}\text { The child's desires and interests are at the centre of } \\
\text { parental activity. }\end{array}$ & .16 & .41 & .54 \\
\hline 3. & $\begin{array}{l}\text { Quality parenting implies that the needs of parents } \\
\text { and children are fulfilled synchronously. }\end{array}$ & -.06 & .58 & .13 \\
\hline 4. & Childrem should obey their parents unconditionally. & .65 & -.25 & .36 \\
\hline 5. & $\begin{array}{l}\text { Parental behaviour is determined by the culture in } \\
\text { which the parent and the child live. }\end{array}$ & .69 & .16 & .09 \\
\hline 6. & $\begin{array}{l}\text { Parental activity is entirely focused on satisfying the } \\
\text { child's needs. }\end{array}$ & .18 & .01 & .86 \\
\hline 7. & $\begin{array}{l}\text { In parenting, parents' behaviour must match the } \\
\text { child's needs. }\end{array}$ & .15 & .31 & .59 \\
\hline 8. & $\begin{array}{l}\text { Children have no right to oppose parental } \\
\text { requirements. }\end{array}$ & .64 & -.27 & .34 \\
\hline 9. & $\begin{array}{l}\text { Traditional values in upbringing are the most } \\
\text { important determinant in parental activity. }\end{array}$ & .68 & -.13 & .39 \\
\hline 10. & $\begin{array}{l}\text { Children must be assured full developmental auto- } \\
\text { nomy. }\end{array}$ & .27 & .59 & -.05 \\
\hline 11. & $\begin{array}{l}\text { Parents can improve their parenting activities for the } \\
\text { well-being of the child. }\end{array}$ & .16 & .66 & .10 \\
\hline 12. & $\begin{array}{l}\text { A child's upbringing is determined by the values of } \\
\text { the parents' family. }\end{array}$ & .61 & .22 & .04 \\
\hline 13. & $\begin{array}{l}\text { While the parent is raising the child, the child is also } \\
\text { raising the parent. }\end{array}$ & -.05 & .63 & -.09 \\
\hline 14. & $\begin{array}{l}\text { In parenting, it is important to adhere to social } \\
\text { norms and the expectations of one's environment. }\end{array}$ & .70 & .01 & .03 \\
\hline 15. & $\begin{array}{l}\text { Parent and child are partners in the educational } \\
\text { process. }\end{array}$ & -.19 & .55 & .30 \\
\hline 16. & $\begin{array}{l}\text { The quality of the parent-child relationship } \\
\text { determines the child's future. }\end{array}$ & .02 & .61 & .20 \\
\hline & $\%$ explained variance & $19 \%$ & $16.7 \%$ & $14 \%$ \\
\hline & $M(s d)$ & $\begin{array}{l}21.79 \\
(4.94)\end{array}$ & $\begin{array}{l}25.49 \\
(2.84)\end{array}$ & $\begin{array}{c}11.5 \\
(2.08)\end{array}$ \\
\hline & Range & $7-35$ & $18-30$ & $3-15$ \\
\hline & Average inter-item $r$ & .37 & .29 & .41 \\
\hline & Cronbach $\alpha$ & .80 & .70 & .67 \\
\hline
\end{tabular}

F1 - egoistic-conventional orientation; F2 - process-interactional orientation; $F 3$ - subjectiveindividualistic orientation 


\section{Instruments for adolescents}

The General Questionnaire for Adolescents was created for the purposes of this study. It consists of two closed type questions to collect data on gender and age, as well as a ten-point self-assessment scale on which participants express their level life satisfaction by choosing responses on a scale of 1 (completely dissatisfied) to 10 (very satisfied).

The Rosenberg Self-Esteem Scale (Rosenberg, 1965), which was completed by adolescents, is a 10-question survey that evaluates general self-esteem. The participants' task is to evaluate the degree to which they agree with each item by choosing responses on a scale of 1 (disagree strongly) to 5 (agree strongly). After the negative items are reverse scored, a linear combination of estimates of all ten items is derived. The reliability is Cronbach $\alpha=.83$ with $\mathrm{M}=31.54$ and $\mathrm{SD}=5.42$. A higher score suggests higher overall self-esteem.

The short form of the UCLA Loneliness Scale consists of 7 statements (for example, No one really knows me well); the participants' task is to assess the degree to which each item relates to him / her on a five-point scale of 1 (I never feel this way) to 5 (I often feel this way). The scale is one-dimensional, and the overall result is formed as a linear combination of estimates on all items, with a higher score indicating higher loneliness. The reliability is Cronbach $\alpha=.80$ with $\mathrm{M}=12.31$ and $\mathrm{SD}=4.88$.

The Quality of Family Interaction Scale (Vulić Prtorić, 2004) measures the quality of interaction with mother and father separately, as well as general family satisfaction. This study used only the general family satisfaction subscale, which consists of 11 items (for example, For me, my family is a source of comfort and satisfaction). The participants' task is to evaluate the extent to which each item refers to them on a five-point scale of 1 (not at all accurate) to 5 (absolutely accurate). A linear combination of estimates on all items is derived. The reliability is Cronbach $\alpha=.90$ with $\mathrm{M}=47.78$ and $\mathrm{SD}=7.64$.

\section{Results}

Table 2 shows the results of Mann-Whitney U-tests, which compare the results of female adolescents and male adolescents on subjec- 
tive well-being measures. A nonparametric test was selected because of the relatively small number of participants in each group $\left(\mathrm{N}_{\text {girls }}=69\right.$; $\mathrm{N}_{\text {boys }}=32$ ).

Table 2. Subjective well-being of adolescents with regard to gender

\begin{tabular}{|l|c|c|c|c|c|}
\hline & $\mathbf{C}_{\text {girls }}$ & $\mathbf{C}_{\text {boys }}$ & $\mathbf{U}$ & $\mathbf{z}$ & $\mathbf{p}$ \\
\hline Life satisfaction & 8.00 & 9.00 & 699.00 & -3.01 & .003 \\
\hline Family satisfaction & 4.52 & 4.64 & 983.50 & -.88 & .380 \\
\hline Self-esteem & 3.00 & 3.40 & 792.50 & -2.27 & .023 \\
\hline Loneliness & 1.71 & 1.36 & 884.50 & 1.61 & .108 \\
\hline
\end{tabular}

The tests showed that female adolescents and male adolescents differ in their levels of self-esteem and life satisfaction, while they display no significant differences in other variables. Male adolescents showed higher levels of self-esteem and life satisfaction than female adolescents.

Table 3 shows the correlation between maternal and paternal parenting measures. There is a significant correlation between mothers' and fathers' assessments of parental self-efficacy. Similarly, mothers' and fathers' assessments of being in the moment with child are also significantly related. The correlations suggest a small to moderate relationship. Also, all the orientations of cognitive parental awareness between mothers and fathers are correlated, with coefficients ranging from .30 to .47 , thus, suggesting a moderate correlation. If we look at the correlation between the two concepts - mindful parenting and cognitive parental awareness - we can conclude that mothers' mindful parenting (parental self-efficacy and being in the moment with the child) is only correlated with the process orientation of cognitive parental awareness, while fathers' mindful parenting is also correlated with the subjective-individualistic and process orientations. Both aspects are highly interrelated in fathers and mothers in mindful parenting. Similarly, different orientations are interrelated in both subsamples within cognitive parental awareness. These coefficients are mostly moderate in magnitude. 
Table 3. Correlation coefficients between parenting variables of mothers and fathers

\begin{tabular}{|l|c|c|c|c|c|c|c|c|c|}
\hline & $\mathbf{1 .}$ & $\mathbf{2 .}$ & $\mathbf{3 .}$ & $\mathbf{4 .}$ & $\mathbf{5 .}$ & $\mathbf{6 .}$ & $\mathbf{7 .}$ & $\mathbf{8 .}$ & $\mathbf{9 .}$ \\
\hline 1. Self-efficacy - mother & & & & & & & & & \\
\hline 2. Focus - mother & $.59 *$ & & & & & & & & \\
\hline 3. Self-efficacy - father & $.31 *$ & .13 & & & & & & & \\
\hline 4. Focus - father & $.25 *$ & $.28 *$ & $.68 *$ & & & & & & \\
\hline $\begin{array}{l}\text { 5. Egoistic orientation } \\
- \text { mother }\end{array}$ & -.01 & .13 & -.05 & -.03 & & & & & \\
\hline $\begin{array}{l}\text { 6. Process orientation } \\
- \text { mother }\end{array}$ & $.40 *$ & $.45 *$ & .15 & .19 & .04 & & & & \\
\hline $\begin{array}{l}\text { 7. Individualistic } \\
\text { orientation - mother }\end{array}$ & .06 & .19 & -.05 & .00 & $.47 *$ & $.34 *$ & & & \\
\hline $\begin{array}{l}\text { 8. Egoistic orientation } \\
- \text { father }\end{array}$ & -.09 & .02 & .06 & .08 & $.47 *$ & .07 & .11 & & \\
\hline $\begin{array}{l}\text { 9. Process orientation } \\
- \text { father }\end{array}$ & $.21 *$ & $.29 *$ & $.37 *$ & $.49 *$ & -.10 & $.32 *$ & .02 & .06 & $.38^{*}$ \\
\hline $\begin{array}{l}\text { 10. Individualistic } \\
\text { orientation - father }\end{array}$ & $.21 *$ & $.20 *$ & $.23 *$ & $.22 *$ & $.23 *$ & .14 & $.30 *$ & $.35 *$ \\
\hline
\end{tabular}
${ }^{*} p<.05$

Table 4 shows the results of correlation analyses, which examined the correlation between parent variables and the subjective well-being of adolescents.

Table 4. Correlation coefficients between mindful parenting, cognitive parental awareness, and indicators of adolescents' subjective well-being

\begin{tabular}{|c|c|c|c|c|c|}
\hline \multirow{2}{*}{ Adolescents } & \multicolumn{5}{|c|}{ Father } \\
\hline & self-efficacy & focus & egoistic & individualistic & process \\
\hline Life satisfaction & .19 & $.29 *$ & -.09 & .09 & $.31 *$ \\
\hline Loneliness & -.14 & $-.20 *$ & .05 & .03 & $-.22 *$ \\
\hline Self-esteem & .19 & .13 & .06 & -.02 & .16 \\
\hline \multirow[t]{3}{*}{ Family satisfaction } & .17 & $.21 *$ & .00 & .16 & $.31 *$ \\
\hline & \multicolumn{5}{|c|}{ Mother } \\
\hline & self-efficacy & focus & egoistic & individualistic & process \\
\hline Life satisfaction & .17 & .12 & -.14 & .00 & .18 \\
\hline Loneliness & .09 & .12 & -.02 & .15 & .02 \\
\hline Self-esteem & .19 & .04 & -.09 & -.13 & .04 \\
\hline Family satisfaction & .13 & $.23 *$ & .02 & .01 & .12 \\
\hline
\end{tabular}

$* p<.05$ 
Table 4 shows that fathers' parenting is more closely correlated with indicators of adolescents' well-being than mothers' parenting. Of all maternal variables, only mothers' being in the moment with the child is significantly correlated with adolescents' family satisfaction. Fathers' being in the moment with the child is significantly positively correlated with adolescents' life satisfaction and family satisfaction, while it is negatively correlated with adolescents' loneliness. It can be concluded that this aspect of paternity is a significant correlate of the subjective well-being of adolescents. The findings are similar for fathers' cognitive parental awareness, wherein process orientation is significantly positively correlated with adolescents' life satisfaction and family satisfaction, but negatively correlated with loneliness. All correlations are small to moderate in magnitude, which indicates the need for further research to explore the established relationships in greater detail.

\section{Discussion}

\section{Adolescents' psychological well-being}

In interpreting the results, we will first examine indicators of the subjective well-being of adolescents as noted in the first research question. The results suggest that male adolescents are more satisfied with life and have higher self-esteem than female adolescents. These results are largely in line with the results of earlier studies that show that selfesteem decreases during adolescence, especially among girls (Robins and Trzesniewski, 2005), and that male adolescents show more life satisfaction and higher self-esteem than female adolescents (Moksnes and Espnes, 2013). The reasons for the higher life satisfaction and selfesteem of male adolescents as compared to female adolescents should be sought in the factors that form these aspects of psychological wellbeing, one of the most important of which is certainly satisfaction with one's physical appearance. Body image is strongly correlated with psychological well-being during adolescence (Pesa et al., 2000), especially for adolescent girls. The relationship between physical self-concept and self-esteem is reciprocal. Higher levels of self-esteem act positively on physical self-esteem, and positive body image in turn increases selfesteem (O'Dea, 2012). Most research suggests female adolescents are significantly more dissatisfied with their physical appearance than male adolescents (Grant et al., 1999; Yates et al., 2004), partly because of peer influence and media-imposed imperatives (Ata et al., 2007); this 
is expected to negatively reflect on both self-esteem and the general psychological well-being of female adolescents.

A significant correlation was found between various indicators of adolescent psychological well-being, which is in line with previous research (Hombrados-Mendieta et al., 2013; Reić Ercegovac et al., 2011; Tu and Zhang, 2014; Mellor et al., 2008). Family satisfaction is one aspect of life satisfaction, and thus a significant correlation between these constructs is both expected and logical. Furthermore, since it is likely that adolescents with higher self-esteem are better at forming, building, and improving relationships with others (especially their peers), make responsible choices, and achieve set goals more easily, they are likely more satisfied and less lonely, which in turn contributes to strengthening their self-esteem. Finally, since the quality of peer relationships contributes to the psychological well-being of adolescents (Rudan, 2004; Žukauskienė, 2014), and since peers are often the most important elements of adolescents' social networks, it is logical that loneliness is negatively correlated with both satisfaction and self-esteem.

\section{The correlation between mindful parenting and the cognitive parental awareness of mothers and fathers}

One of the underlying aims of this research is to investigate whether there is any correlation within the family between mindful parenting and cognitive parental awareness of mothers and fathers. The obtained results regarding the second research problem mostly confirm the existence of a significant correlation. If the family is understood as a complex, dynamic and unique system that cannot be reduced to the mere sum of its constituents, but rather as an "entity" (Janković, 1996; Schaffer, 2000) made up of each member and sub-systems of their interaction, only then can the family, its dynamics, and its functioning be explained. The personality, interests, values, attitudes, and philosophy (Marinoff, 2000) of each individual member of the family significantly affect the quality of relationships and the functioning of the entire family system. In fact, the life and parenting philosophy that results in certain values and attitudes is the one that determines the parenting orientation. The obtained results show a correlation between mothers and fathers in terms of egoistic-conventional, process-interaction, and subjective-individualistic orientation, which was largely expected. Namely, although mothers and fathers are different in many ways, they often have a simi- 
lar vision of their parenting, the ultimate outcome of their parenting, and the values they want to pass on to their children. Similarities in life philosophies is often the reason why young people decide to get married and start a family, so it can be expected that they will share a similar parenting philosophy, resulting in the similar or same parenting orientation with regard to the notion of the child and parental role.

Furthermore, the results of this research have shown that mindful parenting and cognitive parental awareness are related constructs to some extent, with a significant correlation between mindful parenting and the process orientation in mothers, as well as between mindful parenting and both the process and individualistic orientation in fathers. No correlation was found between mindful parenting and the egoisticconventional orientation. These results imply that mindful parenting and parental cognitive awareness are similar but distinct constructs. Mindful parenting and process orientation within cognitive parental awareness share significant amount of similar underlying factors. Cognitive parental awareness represents an entire continuum of different perceptions of parenting and parent-child interactions, while mindful parenting is a positive parenting feature related to actively focusing on the child and parent-child interactions. Furthermore, cognitive parental awareness mostly reflects cognitions that underly parenting behaviors, while mindful parenting is primarily a feature of parental practice.

\section{The correlation between mindful parenting, cognitive parental awareness, and adolescents' psychological well-being}

The main aim of this research is to investigate whether mindful parenting and cognitive parental awareness are correlated with indicators of adolescent psychological well-being as formulated in the third and fourth research questions. The results showed that, of all the variables, only the mother's being in the moment with child is positively correlated with adolescent family satisfaction. In other words, adolescents whose mothers are more focused on them and their interaction report greater family satisfaction. Other mothering variables, unexpectedly, were not correlated with any of the indicators of adolescent well-being. On the other hand, fathers' attention on the child and process orientation were significantly correlated with three out of four indicators of adolescents' psychological well-being, i.e. with life satisfaction, family satisfaction, and loneliness (negative). These results are relatively unexpected, since motherhood is traditionally 
considered a more important determinant of child developmental outcomes. It is possible that time spent with children, as well as the quality of time spent, play an important role in explaining the differences obtained. Mothers usually spend more time with their children than fathers (McBride and Mills, 1993; Altenburger, 2018), and this is usually saturated with numerous nurturing behaviours and other behaviors typically associated with the mother's role, conveying "educational messages" that children quickly get accustomed to, and likely resistant to. However, as being in the moment with the child is significantly correlated with adolescents' family satisfaction, it seems reasonable to assume that adolescents make a clear distinction between repetitive, often superficial messages from the mother and those that are focused and thoughtful. In the less frequent, but probably key moments when fathers become involved and dedicate themselves to the child, they focus on a specific situation. Children probably perceive this behaviour as an important aspect of their relationship, or as specific help which, in the long run, positively affects children's well-being. The father's style of communication, the clear presentation of thoughts and attitudes, resoluteness, authority, etc., may become the child's stronghold, eliminate the feeling of loneliness and increasing the child's family satisfaction. Consequently, the overall life satisfaction of the child grows. Because these interpretations go beyond the aims of this research and the obtained results, the stated assumptions should be explored in further research. The results also show that the father's process-interactional orientation in parenting has a significant affect on adolescents' reduced loneliness and greater family and life satisfaction. Fathers who address parenting as a process, relationship, and role that can be learned and improved, address it responsibly by giving room for equal participation in designing the parenting process to both themselves and their children. The focus on building and improving the relationship with the child is the very quality that determines the child's future (Glasser, 2000; Glasser and Glasser, 2001; Ljubetić, 2012). The fact that, contrary to the expectations, mothers process-interactional orientation was not related to adolescents' outcomes, reflects the need for a better understanding of cognitions underlying mothering behaviors.

\section{Conclusion}

The results of this research are, to a lesser extent, in line with the scarce information available on the relationship between mindful parenting and adolescents' psychological well-being (Moreira et al., 2018). Re- 
search has also indicated differences between the constructs of cognitive parental awareness and mindful parenting, implying the need for further research on these constructs and their role in explaining parenting influences on adolescents' developmental outcomes. Several limitations must be mentioned. This was a correlational study, providing only initial indications of the role of mindful parenting and cognitive parental awareness in adolescents' psychological well-being. Further research is needed to better understand parental awareness and parental mindfulness as determinants in childrens' well-being. Furthermore, data was collected from a convenient sample of adolescents with heterogenous age with more girls than boys. Regardless, one of the contributions of this research is certainly its approach involving the study of whole families - adolescents and both parents. Judging by the results of this research, fathers are very important but unjustly neglected in parenting research. Further research should investigate the contribution of these parent variables to psychological well-being, as well as to other adolescent developmental outcomes.

\section{Literature}

Altenburger, Lauren E.; Schoppe-Sullivan, Sarah J.; Kamp Dush, Claire M. (2018), "Associations between maternal gatekeeping and fathers' parenting quality", Journal of Child and Family Studies, 27, pp. 2678-2689. doi: https://doi.org/10.1007/s10826-018-1107-3

Amato, Paul R.; Fowler, Frieda (2002), "Parenting practices, child adjustment, and family diversity", Journal of Marriage and Family, 64(3), pp. 703-716. doi: https://doi.org/10.1111/j.1741-3737.2002.00703.x

Arendell, Terry (1997), “A social constructionist approach to parenting”, in: Arendell, Terry (ed.), Contemporary Parenting, Thousand Oaks, CA: Sage Publications, pp. 1-44.

Ata, Rheanna N.; Ludden, Alison B.; Lally, Megan M. (2007), "The effects of gender and family, friend, and media influences on eating behaviours and body image during adolescence", Youth Adolescence, 36, pp. 1024-1037.

Bennett, John E.; Grimley, Liam K. (2001), "Parenting in the global community: A cross-cultural/international perspective", in: Fine, Marvin J.; Lee, Steven W. (eds.), Handbook of Diversity in Parent Education. The Changing Faces of Parenting and Parent Education, San Diego, CA: Academic Press, pp. 97-132. doi: https://doi.org/10.1016/b978-012256483-3/50006-x

Bezinović, Petar; Smojver-Ažić, Sanja (2000), "Negativan odnos roditelja i agresivnost adolescenata: Uloga spola roditelja i spola djeteta", Hrvatska revija za rehabilitacijska istraživanja, 36(1), pp. 87-98. 
Bronfenbrenner, Urie (ed.) (2005), Making Human Beings Human: Bioecological Perspectives on Human Development, Sage Publications Ltd.

Cabrera, Natasha J.; Tamis-LeMonda, Catherine S.; Bradley, Robert H.; Hofferth, Sandra L.; Lamb, Michael E. (2000), "Fatherhood in the twenty-first century", Child Development, 71(1), pp. 127-136. doi: https://doi.org/10.1111/1467-8624.00126

Coatsworth, Douglas J.; Duncan, Larisa G.; Greenberg, Mark T.; Nix, Robert L. (2010), "Changing parent's mindfulness, child management skills and relationship quality with their youth: Results from a randomized pilot intervention trial", Journal of Child and Family Studies, 19(2), pp. 203-217.

doi: https://doi.org/10.1007/s10826-009-9304-8

Collins, Andrew W.; Laursen, Brett (2004), "Parent-adolescent relationships and influences", in: Lerner, Richard M.; Steinberg, Laurence (eds.), Handbook of Adolescent Psychology (2nd ed.), Hoboken, NJ: Wiley, pp. 331-361. doi: https://doi.org/10.1002/9780471726746.ch11

Čudina-Obradović, Mira; Obradović, Josip (2006), Psihologija braka i obitelji, Zagreb: Golden marketing.

Demick, Jack (2002), "Stages of parental development”, in: Bornstein, Marc H. (ed.), Handbook of Parenting: Vol. 3: Being and Becoming a Parent, Mahwah, New Jersey: Lawrence Erlbaum Associates, pp. 389-415.

Diener, Ed; Diener, Marissa (1995), "Cross-cultural correlates of life satisfaction and self-esteem", Journal of Personality and Social Psychology, 68, pp. 653-663. doi: https://doi.org/10.1037/0022-3514.68.4.653

Duncan, Larisa G.; Coatsworth, Douglas J.; Greenberg, Mark T. (2009), “A model of mindful parenting: Implications for parent-child relationships and prevention research", Clinical Child \& Family Psychology Review, 12(3), pp. 255-270. doi: https://doi.org/10.1007/s10567-009-0046-3

Erikson, Erik H. (1968), Identity: Youth and Crises, New York: Norton.

Erikson, Erik H. (1980), Identity and the Life Cycle, New York: Norton.

Feeney, Judith A.; Hohaus, Lydia; Noller, Patricia; Alexander, Richard P. (2001), Becoming Parents. Exploring the Bonds between Mothers, Fathers, and their Infants, UK: Cambridge University Press.

doi: https://doi.org/10.1017/cbo9781139164511

Flynn, Denis (2000), “Adolescence”, in: Wise, Inge (ed.), Adolescence, Psychoanalytic Ideas Series, London: Institute of Psychoanalysis, pp. 67-85. doi: https://doi.org/10.4324/9780429471605-5

Freund, Alexandra M.; Ritter, Johannes O. (2009), "Midlife crisis: A debate", Gerontology, 55, pp. 582-591. doi: https://doi.org/10.1159/000227322

Geurtzen, Naline; Scholte, Ron H. J.; Engels, Rutger C.; Tak, Young Ran; van Zundert, Rinka M. (2015), “Association between mindful parenting and ado- 
lescents' internalizing problems: Non-judgmental acceptance of parenting as core element", Journal of Child \& Family Studies, 24, pp. 1117-1128. doi: https://doi.org/10.1007/s10826-014-9920-9

Glasser, William (2000), Teorija izbora - nova psihologija osobne slobode, Zagreb: Alinea.

Glasser, William; Glasser, Carleene (2001), Naći se i ostati zajedno - rješavanje zagonetke braka, Zagreb: Alinea.

Grant, Kathryn E.; Lyons, Aoife L.; Landis, Dana; Cho, Mi Hyon; Scudiero, Maddalena; Reynolds, Linda; Murphy, Julie; Bryant, Heather (1999), “Gender, body image, and depressive symptoms among low-income African American adolescents", Journal of Social Issues, 55, pp. 299-316.

Havighurst, Robert James (1972), Developmental Tasks and Education, New York: David McKay.

Heinrich, Liesl Michelle; Gullone, Eleonora (2006), “The clinical significance of loneliness: A literature review", Clinical Psychology Review, 26, pp. 695-718. doi: https://doi.org/10.1016/j.cpr.2006.04.002

Hombrados-Mendieta, Isabel; García-Martín, Miguel; Jacinto, Luis. (2013), “The relationship between social support, loneliness, and subjective well-being in a Spanish sample from a multidimensional perspective", Social Indicators Research, 114. doi: https://doi.org/10.1007/s11205-012-0187-5

Janković, Josip (1996), Pristupanje obitelji, Zagreb: Alinea.

Juul, Jasper; Jensen, Helle (2010), Od poslušnosti do odgovornosti, Zagreb: Naklada Pelago.

Kalebić Jakupčević, Katija; Reić Ercegovac, Ina (2016), “Dobne i spolne značajke depresivnosti u adolescenciji”, Paediatria Croatica, 60, pp. 139-145. doi: https://doi.org/10.13112/PC.2016

Keresteš, Gordana; Brković, Irma; Kuterovac Jagodić, Gordana (2011), "Predictors of psychological well-being of adolescents' parents", Journal of Happiness Studies, 13, pp. 1073-1089. doi: https://doi.org/10.1007/s10902-011-9307-1

Kušević, Barbara (2011), "Socijalna konstrukcija roditeljstva - implikacije za obiteljsku pedagogiju”, Pedagogijska istraživanja, 8(2), pp. 297-309.

Lachman, Margie E. (2004), "Development in midlife", Annual Review of Psychology, 55, pp. 305-331.

doi: https://doi.org/10.1146/annurev.psych.55.090902.141521

Lansford, Jennifer E.; Laird, Robert D.; Pettit, Gregory S.; Bates, John E.; Dodge, Keneth A. (2014), 'Mothers' and fathers' autonomy-relevant parenting: Longitudinal links with adolescents' externalizing and internalizing behaviour", Journal of Youth and Adolescence, 43(11), pp. 1877-89.

doi: https://doi.org/10.1007/s10964-013-0079-2 
Lippold, Melisa A.; Duncan, Larrisa G.; Coatsworth, Jouglas D.; Nix, Robert L.; Greenberg, Mark T. (2015), "Understanding how mindful parenting may be linked to mother-adolescent communication", Journal of Youth and Adolescence, 44, pp. 1663-1673. doi: https://doi.org/10.1007/s10964-015-0325-x

Ljubetić, Maja (2007), Biti kompetentan roditelj, Zagreb: Mali profesor.

Ljubetić, Maja (2012), Nosi li dobre roditelje roda?! Odgovorno roditeljstvo za kompetentno dijete, Zagreb: Profil International.

Maccoby, Eleanor E.; Martin, John A. (1983), "Socialization in the context of the family: parent-child interaction", in: Mussen, Paul H.; Hetherington, E. Mavis (eds.), Handbook of Child Psychology: Vol. 4. Socialization, Personality, and Social Development, New York: Wiley, pp. 1-101.

Macuka, Ivana (2007), "Skala percepcije roditeljskog ponašanja: Procjena valjanosti”, Suvremena psihologija, 10(2), pp. 179-199.

Marinoff, Lou (2000), Umjesto Prozaca - Platon (filozofija kao psihološka pomoć), Zagreb: V.B.Z. d.o.o.

McBride, Brent A.; Mills, Gail (1993), “A comparison of mother and father involvement with their preschool age children", Early Childhood Research Quarterly, 8(4), pp. 457-477. doi: https://doi.org/10.1016/S0885-2006(05)80080-8

McCaffrey, Stacey (2015), Mindfulness in parenting questionnaire (MIPQ): Development and validation of a measure of mindful parenting (unpublished $\mathrm{PhD}$ thesis), Nova Southeastern University. Available from: https://nsuworks.nova.edu/cps_stuetd/81

McDermot, Dana (2008), Developing Caring Relationships among Parents, Children, Schools, and Communities, Sage Publications, Inc. doi: https://doi.org/10.4135/9781483329437

Mellor, D., Stokes, M., Firth, L., Hayashi, Y.; Cummins, R. (2008), "Need for belonging, relationship satisfaction, loneliness, and life satisfaction”, Personality and Individual Differences, 45, pp. 213-218.

doi: https://doi.org/10.1016/j.paid.2008.03.020

Moksnes, Unni K.; Espnes, Geir A. (2013), "Self-esteem and life satisfaction in adolescents-gender and age as potential moderators", Quality Life Research, 22(10), pp. 2921-2928. doi: https://doi.org/10.1007/s11136-013-0427-4

Moreira, Helena; Gouveia, Maria J.; Canavarro, Maria C. (2018), "Is mindful parenting associated with adolescents' well-being in early and middle/late adolescence? The mediating role of adolescents' attachment representations, self-compassion and mindfulness", Journal of Youth and Adolescence, 47, pp. 1771-1788. doi: https://doi.org/10.1007/s10964-018-0808-7

Moriarty, Michelle L.; Fine, Marvin J. (2001), "Educating parents to be advocates for their children”, in: Fine, M.J.; Lee, S.W. (eds.), Handbook of Diversity in Parent Education, Academic Press, pp. 315-334.

doi: https://doi.org/10.1016/B978-012256483-3/50016-2 
Newberger, Carolyn M. (1977), Parental Conceptions of Children and Childrearing: A Structural-Developmental Analysis, doctoral dissertation, Harvard University, Cambridge, MA.

Newberger, Carolyn M. (1980), "The cognitive structure of parenthood: Designing a descriptive measure", New Directions for Child and Adolescent Development, 7, pp. 45-67. doi: https://doi.org/10.1002/cd.23219800705

Newberger, Carolyn M. (1987), “Time, place and parental awareness: A cognitivedevelopmental perspective on family adaptation and parental care", in: Lancaster, Jane B.; Gelles, Richard J. (eds.), Child Abuse and Neglect: Biosocial Dimensions, New York: de Gruyter, pp. 233-251.

O’Dea, Jennifer A. (2012), "Body image and self-esteem”, in: Cash, Thomas F. (ed.), Encyclopaedia of Body Image and Human Appearance, San Diego, CA: Elsevier Academic Press, pp. 141-147.

doi: https://doi.org/10.1016/B978-0-12-384925-0.00021-3

Pavot, William U.; Diener, Ed (1993), "Review of the satisfaction with life scale", Psychological Assessment, 5, pp. 164-172.

doi: https://doi.org/10.1037/1040-3590.5.2.164

Pesa, Jacqueline A.; Syre, Thomas R.; Jones, Elisabeth (2000), "Psychosocial differences associated with body weight among girl adolescents: The importance of body image", The Journal of Adolescent Health, 26, pp. 330-337. doi: https://doi.org/10.1016/S1054-139X(99)00118-4

Putnick, Diane L.; Bornstein, Marc H.; Hendricks, Charleene; Painter, Kathleen M.; Suwalsky, Joan T.D.; Collins, Andrew W. (2010), "Stability, continuity, and similarity of parenting stress in European American mothers and fathers across their child's transition to adolescence", Parenting: Science \& Practice, 10, pp. 60-77. doi: https://doi.org/10.1080/15295190903014638

Qualter, Pamela; Vanhalst, Janne; Harris, Rebeca; Van Roekel, Eeske; Lodder, Gerine; Bangee, Munirah; Verhagen, Maaike (2015), "Loneliness across the life span”, Perspectives on Psychological Science, 10(2), pp. 250-264. doi: https://doi.org/10.1177/1745691615568999

Reić Ercegovac, Ina (2010), Subjektivna dobrobit tijekom tranzicije u roditeljstvo (Subjective well-being during transition to parenthood) (unpublished $\mathrm{PhD}$ Thesis), Zagreb: University of Zagreb, Faculty of Humanities and Social Sciences.

Robins, Richard W.; Trzesniewski, Kali H. (2005), "Self-esteem development", Current Directions in Psychological Science, 14, pp. 158-162. doi: https://doi.org/10.1111/j.0963-7214.2005.00353.x

Rosenberg, Morris (1965), Society and the Adolescent Self-Image, Princeton, NJ: Princeton University Press. doi: https://doi.org/10.1515/9781400876136

Rudan, Vlasta (2004), “Normalni adolescentni razvoj”, Medix, 10(52), pp. 36-39. 
Satir, Virginia (1983), Conjoint Family Therapy (3rd ed.), Palo Alto, CA: Science and Behavior Books.

Satir, Virginia (1988), The New Peoplemaking, Palo Alto, CA: Science and Behavior Books.

Schaffer, Rudolph H. (2000), Social Development, Massachusetts: Blackwell Publishers Ltd.

Silverstein, Louise B.; Auerbach, Carl F. (1999), "Deconstructing the essential father", American Psychologist, 54(6), pp. 397-407.

Sirridge, Stephen T. (2001), "Parent education for fathers", in: Fine, Marvin J.; Lee, Steven W. (eds.), Handbook of Diversity in Parent Education, Academic Press, pp. 180-196.

Smetana, Judith G.; Campione-Barr, Nicole; Metzger, Aaron (2006), “Adolescent development in interpersonal and societal contexts", Annual Review of Psychology, 57, pp. 255-284.

doi: https://doi.org/10.1146/annurev.psych.57.102904.190124

Tak, Yuly R.; Van Zundert, Rinka M.P.; Kleinjan, Marloes; Engels, Rutger C. (2015), "Mindful parenting and adolescent depressive symptoms: The few associations are moderated by adolescent gender and parental depressive symptoms", Mindfulness, 6, pp. 812-823.

doi: https://doi.org/10.1007/s12671-014-0324-0

Tu, Yidong; Zhang, Shuxia (2014), "Loneliness and subjective well-being among Chinese undergraduates: The mediating role of self-efficacy", Social Indicator Research, 124, pp. 1-18. doi: https://doi.org/10.1007/s11205-014-0809-1

Vansteenkiste, Maarten; Soenens, Bart; Van Petegem, Stijn; Duriez, Bart (2014), "Longitudinal associations between adolescent perceived style of parental prohibition and oppositional defiance and internalization", Developmental Psychology, 50, pp. 229-236. doi: https://doi.org/10.1037/a0032972

Vulić Prtorić, Anita (2004), "Skala kvalitete obiteljskih interakcija - KOBI", in: Zbirka psihologijskih skala i upitnika, Zadar: University of Zadar.

Yates, Alayne; Edman, Jeanne; Aruguette, Mara (2004), "Ethnic differences in BMI and body/self-dissatisfaction among Whites, Asian subgroups, Pacific Islanders, and African-Americans", The Journal of Adolescent Health, 34, pp. 300-307. doi: https://doi.org/10.1016/S1054-139X(03)00305-7

Žukauskiene, Rita (2014), "Adolescence and well-being”, in: Ben-Arieh, Asher; Casa, Feran; Frones, Ivar; Korbin, Jill (eds.), Handbook of Child Well-Being, Dordrecht: Springer, pp. 1713-1738.

doi: https://doi.org/10.1007/978-90-481-9063-8_67 


\title{
ODNOS IZMEĐU USREDOTOČENE SVJESNOSTI U RODITELJSTVU, KOGNITIVNE RODITELJSKE SVJESNOSTI I SUBJEKTIVNE DOBROBITI ADOLESCENATA
}

\author{
Maja Ljubetić, Ina Reić Ercegovac
}

Cilj ovoga istraživanja bio je ispitati povezanost između usredotočene svjesnosti u roditeljstvu, kognitivne roditeljske svjesnosti i subjektivne dobrobiti adolescenata. U istraživanju je sudjelovala 101 obitelj $(N=303)$ koju su činili majka, otac $i$ dijete adolescentne dobi, u rasponu od 10 do 17 godina, $i$ to 69 adolescentica $i$ 32 adolescenta. Primijenjeni su upitnici općih podataka za adolescente i roditelje, upitnik usredotočene svjesnosti u roditeljstvu $i$ upitnik kognitivne roditeljske svjesnosti, dok su adolescenti ispunili skale usamljenosti, zadovoljstva životom $i$ obitelji te općeg samopoštovanja. Rezultati su pokazali da su adolescenti zadovoljniji životom $i$ iskazuju više samopoštovanje u odnosu na adolescentice. Također, utvrđena je značajna povezanost između majki i očeva u većini mjera roditeljstva. Rezultati upućuju na zaključak da su usredotočena svjesnost u roditeljstvu i kognitivna roditeljska svjesnost značajni korelati subjektivne dobrobiti adolescenata kada je riječ o očevima, no ne i majkama.

Ključne riječi: usredotočena svjesnost u roditeljstvu, kognitivna roditeljska svjesnost, adolescenti, zadovoljstvo životom, samopoštovanje, usamljenost 